University of Nebraska - Lincoln

DigitalCommons@University of Nebraska - Lincoln

USDA National Wildlife Research Center - Staff

Publications
U.S. Department of Agriculture: Animal and Plant Health Inspection Service

October 2004

\title{
Development of a high performance liquid chromatography/mass spectroscopy method for the determination of strychnine concentrations in insects used to assess potential risks to insectivores
}

Randal S. Stahl

USDA-APHIS-Wildlife Services, randal.s.stahl@aphis.usda.gov

Wendy M. Arjo

US Department of Agriculture, APHIS/WS, National Wildlife Research Center

Kim K. Wagner

US Department of Agriculture, APHIS/WS, National Wildlife Research Center

Carol Furcolow

US Department of Agriculture, APHIS/WS, National Wildlife Research Center

Dale L. Nolte

USDA-APHIS-Wildlife Services, Dale.L.Nolte@aphis.usda.gov

Follow this and additional works at: https://digitalcommons.unl.edu/icwdm_usdanwrc

anext page for additional aythors

Part of the Environmentalsciences Commons

Stahl, Randal S.; Arjo, Wendy M.; Wagner, Kim K.; Furcolow, Carol ; Nolte, Dale L.; and Johnston, John J., "Development of a high performance liquid chromatography/mass spectroscopy method for the determination of strychnine concentrations in insects used to assess potential risks to insectivores" (2004). USDA National Wildlife Research Center - Staff Publications. 388.

https://digitalcommons.unl.edu/icwdm_usdanwrc/388

This Article is brought to you for free and open access by the U.S. Department of Agriculture: Animal and Plant Health Inspection Service at DigitalCommons@University of Nebraska - Lincoln. It has been accepted for inclusion in USDA National Wildlife Research Center - Staff Publications by an authorized administrator of DigitalCommons@University of Nebraska - Lincoln. 


\section{Authors}

Randal S. Stahl, Wendy M. Arjo, Kim K. Wagner, Carol Furcolow, Dale L. Nolte, and John J. Johnston 


\title{
Development of a high performance liquid chromatography/mass spectroscopy method for the determination of strychnine concentrations in insects used to assess potential risks to insectivores
}

\author{
Randal S. Stahl ${ }^{\mathrm{a}, *}$, Wendy M. Arjo ${ }^{\mathrm{b}}$, Kim K. Wagner ${ }^{\mathrm{b}}$, Carol Furcolow ${ }^{\mathrm{a}}$, \\ Dale L. Nolte ${ }^{\mathrm{b}}$, John J. Johnston ${ }^{\mathrm{a}}$ \\ ${ }^{a}$ US Department of Agriculture, APHIS/WS, National Wildlife Research Center, 4101 LaPorte Avenue, Fort Collins, CO 80521, USA \\ ${ }^{\mathrm{b}}$ US Department of Agriculture, APHIS/WS, National Wildife Research Center, 9730 B Lathrop Industrial Drive, SW, Olympia, WA 98512, USA
}

Received 25 May 2004; accepted 14 September 2004

Available online 18 October 2004

\begin{abstract}
A high performance liquid chromatography/mass spectrometry (HPLC/MS) method was developed in support of a study to assess potential tertiary risks posed to insectivores by strychnine baited pocket gophers (Thomomys sp.). Necropholous insects are primary consumers of pocket gopher carcasses. A field study was conducted to collect insects from strychnine-baited and control pocket gopher carcasses. The majority of the insects collected were from the orders Diptera (flies, assayed separately as adults and larvae), Coleoptera (beetles), and Hymenoptera (ants and wasps, assayed separately). Samples ( $0.5 \mathrm{~g}$ ) were extracted in acetic acid (2\%) and analyzed with the mass spectrometer configured for tandem mass spectrometry. For most of the samples the strychnine concentrations were less than the method limit of detection. However, strychnine concentrations as high as $0.338,0.341,0.698$, and $0.034 \mu \mathrm{g} / \mathrm{g}$ were detected in ants, fly adults, fly larvae, and beetles, respectively. This information collected with the HPLC/MS method is critical for assessing potential non-target hazards for insectivores.
\end{abstract}

(C) 2004 Elsevier B.V. All rights reserved.

Keywords: Strychnine; Mass spectrometry; Tertiary risk

\section{Introduction}

Pocket gophers (Thomomys spp.) are small fossorial rodents indigenous to the western United States. Strychnine bait [steam-rolled oats with 5\% strychnine (4,6-methano6H,14H-indolo[3,2,1-ij]oxepino[2,3,4-de]pyrrolo[2,3-h]quinoline, Fig. 1)] can be applied to an active pocket gopher burrow system as a lethal means of control during reforestation efforts [1,2]. For pocket gophers strychnine has an estimated $\mathrm{LD}_{50}$ of $8 \mathrm{mg} / \mathrm{kg}$ and results in death within 20 min following consumption of a lethal dose [3].

The pocket gopher carcass may pose significant secondary risk as the pocket gopher can store large quantities of bait in

\footnotetext{
* Corresponding author. Tel.: +1 970266 6062; fax: +1 9702666063 .

E-mail address: randal.s.stahl@aphis.usda.gov (R.S. Stahl).
}

cheek pouches, up to 300 grains [4]. Carcasses are rarely recovered above ground and are assumed to be consumed primarily by insects. Insects have been observed to be significant in the decomposition process for rodents and small birds [5-7]. The secondary risk posed to insects by pocket gopher carcasses containing strychnine is not known. However, no mortality was observed in ants consuming strychnine at doses of $0.1-0.5 \mathrm{mg} / \mathrm{kg}[8]$.

To assess the potential exposure and tertiary risks to insectivores feeding on insects that have fed upon pocket gopher carcasses following strychnine baiting, a high performance liquid chromatography/mass spectroscopy (HPLC/MS) method was developed to quantify strychnine in insects. Numerous methods exist for quantifying strychnine using HPLC in baits [9,10], animal tissues, vomitus, or stomach contents $[9,11,12]$, and a few exist for analyzing hu- 


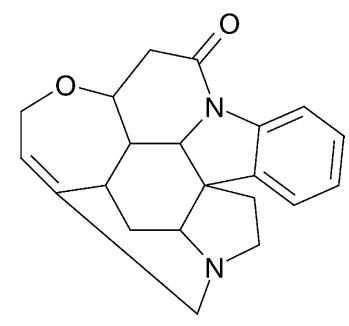

Fig. 1. The structure for strychnine (4,6-methano-6H,14H-indolo[3,2,1ij]oxepino[2,3,4-de]pyrrolo[2,3-h]quinoline).

man urine or blood samples as strychnine has been used to treat non-ketotic hyperglycinemic infants $[13,14]$ or human forensic applications [15]. Methods using both normal phase chromatography [12-14] and reverse phase chromatography with $[10,11,16,17]$ or with out an ion-pairing reagent $[9,16]$ have been developed.

These methods have had the advantage of large sample size, high strychnine concentrations, a single tissue matrix and commonly rely on large extraction volumes using halogenated organic solvents. In this study we were faced with small sample sizes (individuals $<0.2 \mathrm{~g}$ ), whole organism matrices of varying ages and stages of development (highly heterogeneous), and anticipated low concentrations of strychnine. We elected to analyze the samples with HPLC/MS. The advantage of using HPLC/MS for these analyses was that the chromatographic isolation of the strychnine from all co-eluters was not necessary as the mass spectrometer operating in the tandem $\left(\mathrm{MS}^{3}\right)$ mode provided a high degree of specificity and sensitivity for strychnine. To address anticipated problems with highly variable concentration ranges in the samples and possible matrix effects, on-column focusing was evaluated as a means of achieving adequate sensitivity and reproducibility.

\section{Materials and methods}

\subsection{Reagents}

Solvents used included methanol, Fisher Scientific HPLC grade, ethanol, Aldrich reagent grade, ethyl acetate, Burdick \& Jackson, and HPLC grade $\mathrm{H}_{2} \mathrm{O}$, Fisher Scientific, $N, N$ dimethyl formamide, Fisher Scientific. Chemicals used were acetic acid, Fisher Scientific, $\mathrm{NaOH}, 50 \%$ in $\mathrm{H}_{2} \mathrm{O}$, Fisher Scientific, and strychnine, Aldrich, certified $100 \%$ pure.

\subsection{High performance liquid chromatography, on-column focusing of strychnine}

To determine the retention coefficients used to calculate the theoretical maximum injection volume using the approach of Mills et al. [18], a $0.27 \mu \mathrm{g} / \mathrm{mL}$ strychnine standard was analyzed with an Agilent (Palo Alto, CA, USA) 1100 HPLC system with an ultra-violet multiple wavelength detector (MWD-UV), at $\lambda=254 \mathrm{~nm}$. A $10 \mu \mathrm{L}$ sample was injected onto a Phenomenex (Torrence, CA, USA) Luna C$18(2), 5 \mu \mathrm{m}$ particle size, $150 \mathrm{~mm} \times 2.0 \mathrm{~mm}$ column with a Phenomenex Luna C-18(2), $5 \mu \mathrm{m}$ particle size guard column. The retention coefficients were determined in both the sample solvent $10 \% \mathrm{MeOH}: 90 \%$ acetic acid (2\%), and in mobile phase; $80 \% \mathrm{MeOH}: 20 \%$ acetic acid $(2 \%)$ at a flow rate of $0.25 \mathrm{~mL} / \mathrm{min}$. Hold up time was determined by repeatedly injecting $10 \mu \mathrm{L}$ of $N, N$-dimethyl formamide.

\subsection{High performance liquid chromatography/mass spectrometry}

The standards and insect extracts were analyzed with an Agilent 1100 HPLC system with an ultra-violet multiple wavelength detector (MWD-UV) detector connected to a Finnegan LCQ Mass spectrometer. A $50 \mu \mathrm{L}$ sample was injected onto a Phenomenex Luna C-18(2), $5 \mu \mathrm{m}$ particle size, $150 \mathrm{~mm} \times 2.0 \mathrm{~mm}$ column with a Phenomenex Luna C-18(2), $5 \mu \mathrm{m}$ particle size guard column. The separation was performed at a flow rate of $0.25 \mathrm{~mL} / \mathrm{min}$ with a gradient elution, starting with $100 \%$ acetic acid (2\%), ramping to $20 \%$ acetic acid (2\%): $80 \% \mathrm{MeOH}$ over $2 \mathrm{~min}$. This ratio was maintained for an additional $7 \mathrm{~min}$. The column was re-equilibrated with $100 \%$ acetic acid $(2 \%)$ for $15 \mathrm{~min}$. The separation was performed under ambient temperature conditions. Strychnine elution from the column was monitored at $\lambda=254 \mathrm{~nm}$ with the MWD. The electrospray ionization inlet (ESI) on the MS was configured with a capillary temperature of $220^{\circ} \mathrm{C}$, a capillary voltage of $36.0 \mathrm{~V}$ and an ionization spray voltage of $4 \mathrm{kV}$. The sheath and auxiliary gas were $\mathrm{N}_{2}$ with flow rates of 1.275 and $0.3 \mathrm{~L} / \mathrm{min}$, respectively. The divert valve was closed from 0 to 6 min preventing sample from entering the MS detector. Strychnine was quantified using the MS detector with the instrument configured for $\mathrm{MS}^{3}$. Scan events were in the positive ion mode $(70-350 \mathrm{~m} / \mathrm{z})$ with one microscan using a $400 \mathrm{~ms}$ ion injection time. The parent ion isolated was $m / z=335$. At $\mathrm{MS}^{2}$ the isolated fragment was $m / z=264$. At MS 3 the fragment was $m / z=234$. This ion was quantified for the determination of strychnine concentration in the samples. Strychnine eluted at approximately $7.2 \mathrm{~min}$.

\subsection{Sample extraction and analysis}

The extraction was developed for a $0.5 \mathrm{~g}$ cricket sample (approximately two crickets). Recoveries were verified with fortified adult and larval flies (Diptera) as well as ants (Hymenoptera). Additional insect matrices analyzed with the method included wasps (Hymenoptera), other Hymenoptera, Coleoptera, and other insects. Lack of sufficient sample precluded verifying the method for all matrices. Smaller sample sizes were analyzed using the same procedure. The extraction consisted of adding $10 \mathrm{ml}$ of $2 \mathrm{M} \mathrm{NaOH}, 5 \mathrm{~mL}$ of $5 \%$ ethanol in ethyl acetate followed $5 \mathrm{~mL}$ of hexane to a sample. The mixture was ground with a Brinkmann (Westbury, NY, USA) Polytron tissue homogenizer, and the test tube was capped 
and shaken on a mechanical shaker on the high setting for $10 \mathrm{~min}$. This solution was centrifuged for $2 \mathrm{~min}$ after which the organic layer was collected and the organic extraction repeated. The organic volumes were combined and evaporated to dryness under a mild stream of $\mathrm{N}_{2}$ at $60^{\circ} \mathrm{C}$. The sample was reconstituted in $5 \mathrm{~mL}$ of $90 \%$ acetic acid (2\%) $10 \% \mathrm{MeOH}$, shaken for $10 \mathrm{~min}$, and sonicated for $15 \mathrm{~min}$. An aliquot was filtered through a Teflon filter $(0.45 \mu \mathrm{m}$ pores $)$ into an $\mathrm{LC}$ vial and capped prior to analysis with the LC/MS. When sufficient sample mass was available, samples were sub-sampled prior to analysis. However, in most cases sample mass prevented replicate sampling.

\section{Method development and validation}

The linear range of the method was established using standards at concentrations of $0.0027,0.0055,0.011,0.055$, $0.11,0.164,0.219$, and $0.274 \mu \mathrm{g} / \mathrm{mL}$, injected in triplicate, using the LC/MS method described previously. A linear regression equation was calculated with peak areas (from $m / z=234)$ as the dependent variable and concentration as the independent variable (SAS, Cary, NC, USA, version 8.2). The residuals and the correlation coefficient were calculated to assess linearity. The peak heights from replicate injections of the $0.0027 \mu \mathrm{g} / \mathrm{mL}$ standard and the baseline noise from a solvent blank $(10 \% \mathrm{MeOH} / 90 \%$ acetic acid (2\%)) were used to calculate the instrument limit of detection (ILOD) where the ILOD was defined as a signal peak height three times the average baseline noise, measured peak to peak. When analyzing insect samples, a standard curve from a single stock source was injected every 10 samples.

Crickets were obtained at a local pet shop and frozen prior to analysis. Samples $(\sim 0.5 \mathrm{~g})$ were weighed into a glass test tube and fortified with $25 \mu \mathrm{L}$ of a $1 \mu \mathrm{g} / \mathrm{mL}$ or $50 \mu \mathrm{L}$ of a $10 \mu \mathrm{g} / \mathrm{mL}$ strychnine standard stock solution. Four replicates at each concentration were assayed at three different days to provide for inter and intra-day comparisons. The method limit of detection was determined from the cricket samples fortified with $25 \mu \mathrm{L}$ of a $1 \mu \mathrm{g} / \mathrm{mL}$ strychnine standard and unfortified controls. The MLOD was defined as the minimum signal that would produce a peak height three times the baseline noise, measured peak to peak, in the unfortified controls. The method limit of quantitation was calculated as the minimum signal that would produce a signal five times the baseline noise, measured peak to peak. Recovery efficiency of the method was confirmed for ants and adult and larval flies collected from control (no strychnine) pocket gopher carcasses fortified with $50 \mu \mathrm{L}$ of a $10 \mu \mathrm{g} / \mathrm{mL}$ strychnine standard. Three replicates of each insect matrix were assayed for comparison with the fortified cricket results. Insufficient sample size precluded additional treatments. During daily sample analysis, a set of fortified cricket samples (two control, two at $\sim 0.05 \mu \mathrm{g} / \mathrm{g}$, two at $\sim 1 \mu \mathrm{g} / \mathrm{g}$ ) were extracted and analyzed for QC purposes.

\subsection{Insect collection}

Insects were collected from the pocket gopher carcasses at selected field sites in the Rogue River National Forest, WA during August 1999. Carcasses ( $n=5$ strychnine treated, $n=5$ controls) from pocket gophers that had been collected following a baiting application in the field were placed in wire insect traps and set in the field for 5 days. Traps were checked daily and insects were collected. After the fifth day, the carcasses were necropsied and Diptera larvae were collected. The insects were sorted into the following categories; ants, wasps, other Hymenoptera, Diptera adults (fly), Diptera larvae (fly), Coleoptera, and all others. The insects were frozen until analyzed. Means, standard deviations, and maximum values observed, were determined for the insects analyzed using the method described.

\section{Results and discussion}

\subsection{Calculation of maximum injection volume}

The retention coefficient for strychnine in the mobile phase averaged $5.77(N=3)$ with a mean plate number of 26,757 . The mean retention $(N=3)$ coefficient for the sample solvent was 22.19 with a mean plate number of 338. A maximum injection volume of $73 \mu \mathrm{L}$ was calculated for the chromatography conditions to be used in the method using these values [18]. We elected to use a $50 \mu \mathrm{L}$ injection volume to allow for possible matrix interferences.

\subsection{Proposed ion fragmentation}

Electrospray ionization (ESI) is a relatively soft ionization source for producing ion fragments, similar to chemical ionization in GC/MS. The proposed ion fragments that we detected at each stage of the tandem mode of operation of the MS are presented in Fig. 2 and are similar to those expected for strychnine using EI/GC/MS [19].

\subsection{Method validation}

The standard curve for strychnine was determined to be linear across the range of $0.0027-0.274 \mu \mathrm{g} / \mathrm{mL}$ with an $R^{2}=0.99$. The ILOD determined from the peak heights for the $0.0027 \mu \mathrm{g} / \mathrm{mL}$ standard and the solvent blanks was $0.00016 \mu \mathrm{g} / \mathrm{mL}$.

The method was developed and validated using crickets due to the ease with which they could be acquired. The decision to use crickets as a matrix was not anticipated to bias the method as there is a high degree of selectivity when using $\mathrm{MS}^{3}$. A gradient elution was used with the LC to elute as much of the co-extracted material off the column as possible before passing the strychnine into the mass detector. Output from the multiple wavelength detector was monitored for each sample as a means of tracking column performance. 


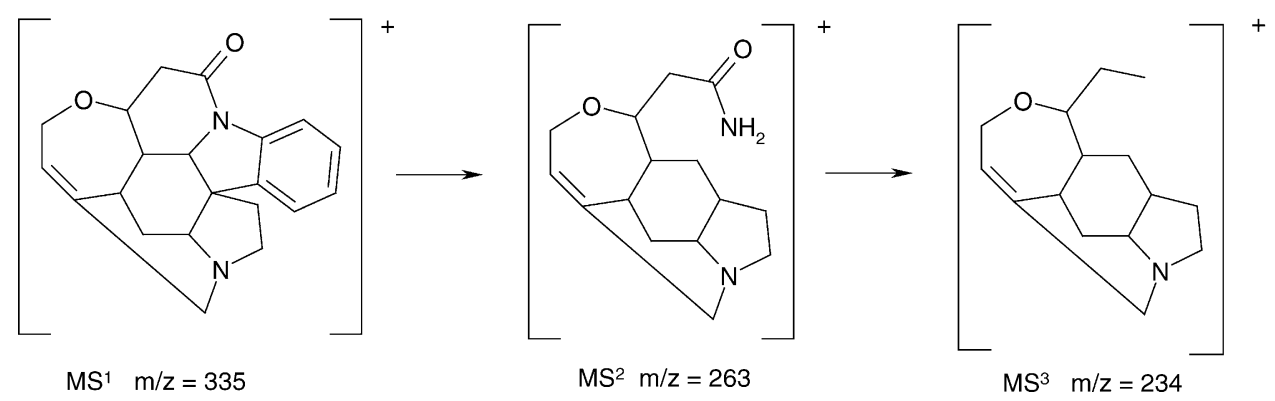

Fig. 2. Proposed ion fragments detected at each stage during tandem mass spectrometry $\left(\mathrm{MS}^{3}\right)$.

Table 1

Percent recovery data for fortified cricket, ant, fly adult and larvae samples

\begin{tabular}{llllllcll}
\hline Matrix & Day & $n$ & Mean mass $(\mathrm{g})$ & Treatment level & Mean fortified level $(\mu \mathrm{g} / \mathrm{g})$ & Recovery $(\%)$ & $\mathrm{CV}(\%)$ & Mass vs. \% rec $\left(R^{2}\right)$ \\
\hline Cricket & 1 & 5 & $0.5272 \pm 0.0828$ & Control & & $<M L O D$ & $\mathrm{nc}$ & $\mathrm{nc}$ \\
& & 5 & $0.6187 \pm 0.0937$ & Low & 0.0417 & $89.6 \pm 4.7$ & 5.2 & 0.417 \\
& & 5 & $0.5235 \pm 0.0523$ & High & 0.963 & $77.9 \pm 4.9$ & 6.3 & 0.337 \\
& 2 & 4 & $0.5642 \pm 0.0523$ & Control & & $<M L O D$ & $\mathrm{nc}$ & $\mathrm{nc}$ \\
& & 4 & $0.6087 \pm 0.0410$ & Low & 0.0429 & $64.6 \pm 6.6$ & 10.2 & 0.689 \\
& & 5 & $0.6359 \pm 0.0686$ & High & 0.817 & $76.9 \pm 11.4$ & 14.8 & 0.872 \\
& 3 & 5 & $0.5298 \pm 0.0331$ & Control & & $<M L O D$ & $\mathrm{nc}$ & $\mathrm{nc}$ \\
& & 5 & $0.5186 \pm 0.0257$ & Low & 0.0483 & $80.6 \pm$ hbox 9.5 & 11.8 & 0.076 \\
Ant & & 5 & $0.5625 \pm 0.0523$ & High & 0.891 & $79.1 \pm 3.4$ & 4.3 & 0.441 \\
Fly adults & 4 & 3 & $0.3377 \pm 0.0585$ & High & 1.63 & $75.9 \pm 2.4$ & 3.2 & 0.931 \\
Fly larvae & 5 & 3 & $0.4767 \pm 0.0607$ & High & 1.14 & $70.3 \pm 3.8$ & 5.4 & 0.886 \\
\hline
\end{tabular}

Inter- and intra-day recoveries for strychnine (Table 1) for the low level fortification $(25 \mu \mathrm{L}$ of a $1 \mu \mathrm{g} / \mathrm{mL}$ standard stock solution) ranged from $64.6 \pm 6.6$ to $89.6 \pm 4.7$. For the high treatment fortifications $(50 \mu \mathrm{L}$ of a $10 \mu \mathrm{g} / \mathrm{mL}$ standard stock solution) recoveries ranged from $76.9 \pm 11.4$ to $79.1 \pm 3.4$. Where low recoveries occurred, there tended to be a significant correlation $\left(R^{2}\right)$ between sample mass and decreased recovery when a linear regression of percent recovery was calculated against sample mass (Table 1). The average MLOD for the 3 days the fortified crickets were analyzed, calculated from the low fortification treatment samples and the controls, was $0.00663 \mu \mathrm{g} / \mathrm{g}$. The limit of quantitation for the fortified cricket samples was $0.014 \mu \mathrm{g} / \mathrm{g}$. On-column focusing provided adequate sensitivity but not repeatability and in hind-sight the inclusion of an internal standard combined with on-column focusing would have increased the robustness of the method.

There was a trade-off made in selecting to measure strychnine using $\mathrm{MS}^{3}$ between recovery and limit of detection. There is less analyte reaching the detector for each increase in $\mathrm{n}$ for $\mathrm{MS}^{n}$ while there is a decrease in the noise level observed in the baseline. Additionally, with increases in $n$ there is an increase in the probability that the peak detected is associated with the analyte being quantified. The percent recoveries (Table 1) for ants, adult flies, and fly larvae were $75.9 \pm 2.4$, $70.3 \pm 3.8$, and $64.8 \pm 5.1$, respectively. These were consistent with those observed in the fortified cricket matrices and considered acceptable for the method.

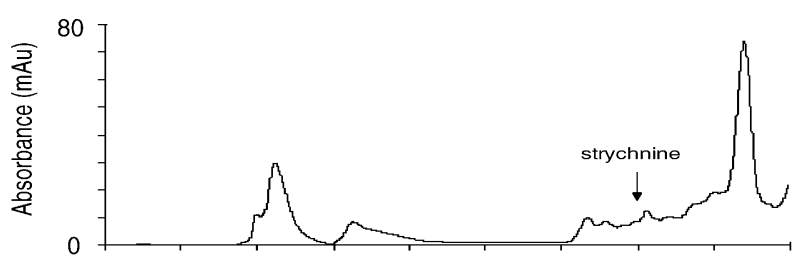

(A)

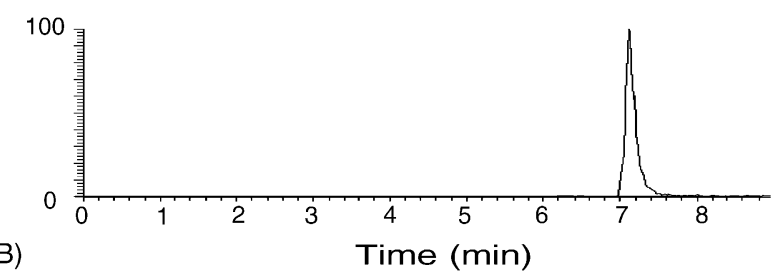

(B)

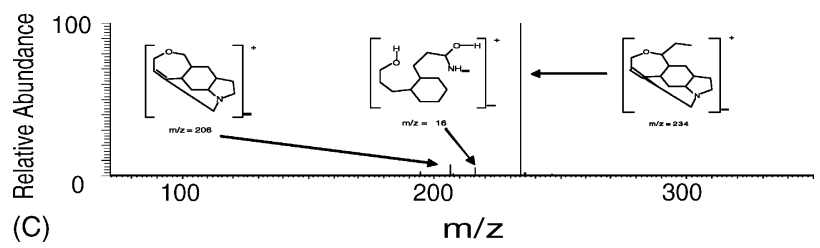

Fig. 3. The UV-detector output at $\lambda=254 \mathrm{~nm}$ (A), the MS detector output at $\mathrm{m} / \mathrm{z}=234$ (B), and the ion mass spectrum from $\mathrm{m} / z=70-350$ at $7.27 \mathrm{~min}(\mathrm{C})$ for a composite ant sample collected from a strychnine bait treated pocket gopher carcass. Signals corresponding to $100 \%$ relative abundance in (B) and (C) are 8.24E5 and 9.5E5, respectively. Proposed ion fragments at $\mathrm{m} / \mathrm{z}=206$, 216 and 234 produced from the ion fragment parent $\mathrm{m} / \mathrm{z}=264$ are identified in $(\mathrm{C})$. 
Table 2

Strychnine concentrations in insects from control and treated carcasses

\begin{tabular}{|c|c|c|c|c|c|}
\hline Insect & Treatment & $N$ & Mean concentration $(\mu \mathrm{g} / \mathrm{g})$ & Standard deviation & Maximum concentration $(\mu \mathrm{g} / \mathrm{g})$ \\
\hline \multirow[t]{2}{*}{ Ants } & Control & 13 & - & - & $<$ MLOD \\
\hline & Strychnine & 13 & 0.130 & 0.149 & 0.338 \\
\hline \multirow[t]{2}{*}{ Wasps } & Control & 9 & - & - & $<$ MLOD \\
\hline & Strychnine & 10 & 0.006 & 0.016 & 0.051 \\
\hline \multirow[t]{2}{*}{ Other Hymenoptera } & Control & 2 & - & - & $<$ MLOD \\
\hline & Strychnine & 6 & 0.031 & 0.064 & 0.161 \\
\hline \multirow[t]{2}{*}{ Coleoptera } & Control & 8 & - & - & $<$ MLOD \\
\hline & Strychnine & 13 & 0.004 & 0.011 & 0.034 \\
\hline \multirow[t]{2}{*}{ Diptera adult } & Control & 26 & - & - & $<$ MLOD \\
\hline & Strychnine & 25 & 0.040 & 0.112 & 0.341 \\
\hline \multirow[t]{2}{*}{ Diptera larvae } & Control & 6 & - & - & $<$ MLOD \\
\hline & Strychnine & 4 & 0.366 & 0.232 & 0.698 \\
\hline \multirow[t]{2}{*}{ Other insects } & Control & 3 & 0.167 & 0.289 & 0.501 \\
\hline & Strychnine & 5 & - & - & $<$ MLOD \\
\hline
\end{tabular}

\subsection{Insect sample analysis}

A chromatogram for ants collected from a strychnine treated carcass (Fig. 3) is representative of the output of the method when used to analyze samples. The low strychnine concentrations in the samples made it difficult to use the UV-MWD to determine concentration (Fig. 3A). The concentration of strychnine detected in this sample was $0.244 \mu \mathrm{g} / \mathrm{g}$.

The majority of the insects collected from the carcasses and analyzed with the method described above (Table 2) were either ants or flies (adults and larvae). Other insects collected included wasps (Hymenoptera), beetles (Coleoptera), bees (classified as other Hymenoptera) and tics (classified as other insects). In most cases, insect samples were not sub-sampled but analyzed with $n=1$ as there was insufficient sample mass to analyze replicates. The standard deviations around the means reflect the non-normal distribution of the samples that had quantifiable levels of strychnine. The majority of the samples analyzed had strychnine concentrations below the MLOD, which averaged $0.0067 \mu \mathrm{g} / \mathrm{g}$, for fortified cricket samples extracted with each day's samples. However, strychnine concentrations as high as $0.338,0.341,0.698$, and $0.034 \mu \mathrm{g} / \mathrm{g}$ were detected in ants, fly adults, fly larvae, and beetles, respectively.

The data generated with this method have been incorporated into a risk assessment where risk quotients [20] were calculated for pigeon (Passer domesticus), mouse (Mus musculus), and bull frog (Rana catesbeiana) assuming that for each species the daily diet consisted entirely of insects containing strychnine at $0.276 \mu \mathrm{g} / \mathrm{g}$ (concentration at the 95th percentile) [21]. In all three cases, the risk to the insectivore was negligible based on calculated risk quotient values considerably less than 0.1 .

\section{Conclusion}

The method developed to determine strychnine concentration in insects that have fed on carcasses of pocket gophers proved to be robust and sensitive. The results from a preliminary study indicated that insects do accumulate sufficient strychnine to be detectable in a sample size of $0.5 \mathrm{~g}$. However, the levels of strychnine we observed do not appear to pose a significant risk to insectivores. The method we developed will be used in future studies to expand the assessment of tertiary risk that strychnine baited pocket gopher carcasses pose to insectivores.

\section{Acknowledgements}

We would like to thank Bruce Kimball for his assistance in operating the LCQ. Mention of commerical products is for identification only and does not constitute endorsement by the USDA.

\section{References}

[1] P.R. Cunnutt, in: R.H. Dana (Ed.), Proceedings of the Vertebrate Pest Conference, University of California, Davis, CA, 1970, p. 120.

[2] V.G. Barnes, Pocket Gophers and Reforestation in the Pacific Northwest: A Problem Analysis, U.S. Fish and Wildlife Special Scientific Report 155, p. 18.

[3] D. Nolte, K. Wagner, in: H.J. Pelz (Ed.), Advances in Vertebrate Pest Management, 2001, p. 59.

[4] P.L. Hegdal, T.A. Gatz, in: C.C. Siebe (Ed.), Proceedings of the Vertebrate Pest Conference, University of California, Davis, CA, 1976, p. 258.

[5] D. Sullivan, in: A.C. Crabb, R.E. Marsh (Eds.), Proceedings of the Vertebrate Pest Conference, University of California, Davis, CA, 1988, p. 169. 
[6] G.W. Witmer, M.J. Pipas, D.L. Campbell, Int. Biodeterior. Biodegrad. 36 (1995) 177.

[7] M.E. Tobin, R.A. Dolbeer, J. Field Ornithol. 61 (1990) 237.

[8] W. Kostowski, J. Beck, J. Meszaroros, Pharm. Pharmacol. 17 (1965) 253.

[9] M.D. Crouch, C.R. Short, J. Assoc. Off. Anal. Chem. 61 (1978) 612.

[10] G.T. Gale, Determination of strychnine by high performance liquid chromatography, Strychnine EPA-3, U.S. Environmental Protection Agency Manual of Chemical Methods for Pesticides and Devices, second ed., AOAC International, Arlington, VA, 1992.

[11] J.J. Hoogenbloom, C.G. Rammell, J. Assoc. Off. Anal. Chem. 68 (1985) 1131.

[12] R.T. Hunter, R.E. Creekmur Jr., J. Assoc. Off. Anal. Chem. 67 (1984) 542.

[13] L. Alliot, G. Bryant, P.S. Guth, J. Chromatogr. 232 (1982) 440.
[14] T. Egloff, A. Niederwieser, K. Pfister, A. Otten, W. Steiner, R. Gitzelmann, J. Clin. Chem. Clin. Biochem. 20 (1982) 203.

[15] Z. Wang, J. Zhao, J. Xing, Y. He, D. Guo, J. Anal. Toxicol. 28 (2004) 141.

[16] J.J. Johnston, E.E. Petty, I. Okuno, D.L. Nolte, J. Chromatogr. B 670 (1995) 73.

[17] B.A. Kimball, C.A. Furcolow, J. Agric. Food Chem. 43 (1995) 700.

[18] M.J. Mills, J. Maltas, W.J. Lough, J. Chromatogr. A 759 (1997) 1.

[19] F.W. McLafferty, Interpretation of Mass Spectra, third ed., University Science Books, Mill Valley, CA, USA, 1980, p. 303.

[20] B.E. Sample, G.W. Sutter, Estimating exposure of terrestrial wildlife to contaminants, Publication ES/ER/TM-125, U.S. Environmental Protection Agency, U.S. Government Printing Office, Washington, DC, 1997.

[21] W.M. Arjo, K.K. Wagner, D.L. Nolte, R.S. Stahl, J.J. Johnston, 2003, submitted for publication. 